\title{
Exploratory Study on the Determinants of Informal Employment in the Current Mexican Return Migration
}

\author{
Julio Santiago Hernández, PhD. \\ Department of Economics and Political Science \\ University Center of Tonalá, Universidad de Guadalajara \\ Jalisco, México. \\ Edilma De Jesus Desidério, PhD. \\ Department of Economics and Political Science \\ University Center of Tonalá, Universidad de Guadalajara \\ Jalisco, México. \\ Nicéforo Aguillar Delgadillo \\ Migration Policy Unit \\ Ministry of the Interior of México \\ México City, México.
}

\begin{abstract}
The purpose of this work is to generate updated knowledge, make the determinants that have been characterizing the returning migrant working population that may show a higher incidence of informal employment. A dichotomous dependent variable model is generated to analyze the dynamics of the labour market, based on the data provided by the National Survey of Occupation and Employment (Encuesta Nacional de Ocupación y Empleo - ENOE), from the first quarter of 2010 to the first quarter of 2017. The results suggest that a higher level of informal employment is associated with lower levels of schooling, living in a rural area and low incomes.
\end{abstract}

Keywords: International migration, labour market, informal employment, México.

\section{Introduction}

After the economic crisis of 2008 that registered the worse rates of unemployment and before the loss of employment, particularly among Mexican migrants -together with the increase in migratory controls in the United States-, the return of co-nationals caused a massive fear that propagated in Mexico. After some years, and with much more information it is known that this did not happen but what happened instead was a deceleration of the flow that had an impact on the growth of the Mexican resident population in the United States.

The migration scenario that abovementioned economic crisis left is one in which the flow of departure of Mexican migrants to the United States is compensated with the flow of returnees, generating a null migratory balance, or at least close to zero (Passel, Cohn and Gonzalez, 2012). In fact, the null migratory net balance generated by current economic crisis takes place in a context in which the emigration and return flows continues involving, every year, hundreds of thousands of people (Canales, 2012) and that repatriations of co-nationals have remained high in recent years: 2,8 million of events between 2008 and 2013, together with voluntary flow, have consolidated Mexico as a country of return (SEGOB, 2014).

The 2010 population census counted a total amount of 1.1 million of international migrants, of which 351 thousand returned to the country. That is to say, three out of ten people who migrated returned to the country in the five-year period 2005-2010. In contrast, the 2000 population census showed that from 1.6 million international migrants, 285 thousand had returned, which meant the return to Mexico of only 17 percent in the five-year period 1995-2000 (INEGI, 2011).

Meanwhile the returning increase and decrease in immigration happened, the number of people who were born outside the national territory doubled, passing from 492 to 961 thousand, of which nearly $60 \%$ were children born in another country (INEGI, 2011). It is important to mention the high participation of the population residing in the United States, which in 2010 represented nearly $92 \%$ of recent international immigrants (INEGI,2011), being considered that many of them were Mexican who returned to the country of their parents (Mestries, 2013: 174). 
In this new scenario of economic recession, new challenges arise in the study of reintegration of returning international migrants. Not only because the current circumstances prevent some returning migrants to restore them effectively into favourable economic conditions, but due to the returnees' profiles have changed in the last decade, impacting in their social and professional insertion arrangements (Rivera, 2011).

The informal economy, besides being a complex phenomenon, pre-exists in the economic reality of many countries, particularly in the least developed ones, and it produces important effects on their economies. In the case of Mexico, the informal economy has been rising in recent decades due to the scarce and erratic economic growth, according to the National Survey of Occupation and Employment, which reported that the Informal Employment Rate for the first quarter of 2015 reached $58 \%$.

The international returnees had faced the situation of scarce employment and job, preventing that some of them do not find a place in the formal work market, so they must insert in the informal sector of the economy, like retailers in weekend rolling markets, or as non-regulated taxi drivers, part-time carriers, bricklayers, street vendors and/or by catalogue, among others; of course that labour reinsertion does not mean, in most of cases an ascending social mobility (Rivera, 2011).

As pointed out by the International Labour Organization (ILO), "the informal economy is where the biggest problems in terms of social protection are located, and where the discrimination and vulnerability are more generalized" (Trejos, 2001).

Considering the new challenges for those who decide to return to the country and for those who govern them and generate public policies for this population, it is necessary a diagnosis about the returnees population the informal sector and their causes or determinants, as well as an identification of those in addition to the tendency in time. The proposal of this paper aims to explore the possible scenarios that could determine the practice of informality of migratory populations' daily life in their return to Mexico.

Taking into consideration the theoretical and methodological approaches to analyze this problem, paragraphs are structured in: Material sources and data to understand the determinants of the formal job; it displays the methodological design and the source used for that, which is the National Survey of Occupation and Employment (ENOE, by its acronym in Spanish). The second, Statistical method: approaches to the probability of occurrence of return migrant population and the approach to the analysis, which describes the method of proceeding from the analysis and forecasting of the determinants of labour informality, built from the logistic regression model.

The third section, Results of the determinants of the informality among Mexican return migrants, exposes in a more accurately way, the determinants that influence the decision of working in informal activities, considering some variables that literature suggests as key, such as the kinds of jobs to which workers have access. In this section, the analysis with the approach to an Estimated model of return migrants is complemented.

Finally, same reflections are pointed out about the status of the statically constructed presentations for the return migrant populations, the reality forged for the new flows based on determinants towards informality and some recommendations that must be considered in the implementation of public migratory policy.

\section{Material sources and data to understand the determinants of the formal employment}

The source of information used for this research, which is the National Survey of Occupation and Employment (ENOE), provides results in a variety of modalities; consult of previously designed and tabulated indicators at a national scale, by state and city (locations equal or less to 100000 and more inhabitants). It generates information on the occupational situation of Mexico, the incorporation in labour markets such as: working population, unemployed population or population that is trying to incorporate to work, with no results yet; not economically active population or that one that remains outside of labour markets.

The scheme of rotational panels of the ENOE sample allows identifying, from the second visit in selected dwellings, the new residents in their homes and the definitive absentees of such. Among the first ones, it can be mentioned the newborns and immigrants. Among the second ones, it is found the deceased people who emigrate. Thus, it allows to measure demographical phenomena such as birth rate, mortality and migration (in particular, the returning population), given the advantage that represents the great size of its quarterly sample and the opportunity of its results (Table 1). 
Table 1. Classification of the records according to the demographic event caught by the ENOE

\begin{tabular}{|c|c|c|c|}
\hline $\begin{array}{l}\text { Type of } \\
\text { record }\end{array}$ & Reasons of change & Destiny/origin & Subpopulation \\
\hline \multirow{3}{*}{ Absent } & Decease & N/A & Deaths \\
\hline & \multirow{2}{*}{$\begin{array}{l}\text { Work, study, marriage or } \\
\text { union, separation or divorce, } \\
\text { health issues, meeting with the } \\
\text { family; lack of public security, } \\
\text { others }\end{array}$} & Another state & Internalemigrantornationalemigrant \\
\hline & & Another country & International emigrant \\
\hline \multirow{3}{*}{$\begin{array}{l}\text { New } \\
\text { Resident }\end{array}$} & Was born & N/A & Birth \\
\hline & \multirow{2}{*}{$\begin{array}{l}\text { Work, study, marriage or } \\
\text { union, separation or divorce, } \\
\text { health issues, meeting with the } \\
\text { family; lack of public security, } \\
\text { others }\end{array}$} & Other state & $\begin{array}{l}\text { Internal immigrant } \\
\text { or national immigrant }\end{array}$ \\
\hline & & Another country & International immigrant \\
\hline
\end{tabular}

Source: Own compilation based on ENOE, INEGI

\section{Statistical method: approaches to the probability of occurrence of return migrant population and the approach to analysis}

The statistical approach that is used lays on the methods of logistic regression analysis that is a statistical technique formulated in order to predict the behaviour of a dichotomous dependent variable in function of one or more independent variables. It is one of the widely used statistical tools, with a greater capacity of data analysis concerning social investigation.

The main purpose of this technique is to predict how the presence or absence of several factors influences in the probability of occurrence of an event (dichotomous or binary), and the value or level of such. The prediction is based on a set of independent variables with explanatory capacity regarding to the dependent variable; the logistic regression consists of obtaining a lineal function of the independent variables that may allow classifying the individuals in one of the two levels or groups, established by the two values of the dependent variable.

The logistic regression is chosen for the analysis due to four particular reasons: 1. It allows to input a mix of quantitative and categorical variables; 2. It allows to calculate the risk quantification parameters known in literature as "odds ratio" from the regression coefficients $(\beta)$ of the independent variables that were input in the model; 3 . The dependent variable (the one that is desired to be modelled, Y) is categorical, (binary in this case), which simplifies the representation of phenomena in general; 4 . The logistic regression expresses the probability of occurrence of a given event as a function of certain variables that are regarded as relevant or influential. If the fact that we want to model or predict is represented by $\mathrm{Y}$ (the dependent variable), and the explanatory variables $\mathrm{k}$ (independent and control) are expressed by $\mathrm{X}_{1}, \mathrm{X}_{2}, \mathrm{X}_{3}-\cdots-\mathrm{X}_{\mathrm{k}}$, the general equation (or logistic function) is:

$$
P(Y=1)=\frac{1}{1+\exp \left(-\alpha-\beta_{1} X_{1}-\beta_{2} X_{2}-\beta_{3} X_{3}-\cdots-\beta_{k} X_{k}\right.}
$$

Where: $\alpha, \beta_{1}, \beta_{2}, \beta_{3}, \cdots, \beta_{k}$ are the parameters of the model, and $\exp$ denotes the exponential function. This exponential function is a simplified expression, which corresponds to elevate the number $e$ to the power contained within the parenthesis, wheree: is the Euler number or constant, or the base of Neperian logarithms, whose value is 2.718 approximated to the thousandth (Jay, 2008).

In recent years in Mexico, different estimates have emerged for a possible massive return, ranging between 350 thousand to 3 million of Mexican migrants that go back (Alarcón et al., 2008; BBVA, 2012); considering the possible long term benefits that the return of highly qualified migrants would have (Tuirán and Avila, 2013).

Based on the information coming from the construction of panels of the National Survey of Occupation and Employment (ENOE) 2010-2016, the statistics about the return migration to Mexico that comes from the United States, its socio-demographic and work profile are analyzed. In such analysis, it is considered as Mexican return migrant people born in Mexico that return to live to this country at the age of 15 or older. It is taken as a reference for the terms "formal employment" and "informal employment" the definition from the ENOE conceptual and methodological framework document glossary. 
ENOE defines formal employment as the wage workforce that has access to a social security scheme, while the informal is related to activities that are carried out with households' resources, even though those are not well identified and duly established companies, independent from their households (INEGI, 2014; Varela et al., 2013).

There view of the figures from the ENOE suggests a shortening in the flow of Mexican returning migrants in recent years, taking into account as a precedent that before the economic crisis in 2008, the flow of Mexican returning migrants diminished.

By 2005, for every ten thousand common residents in our country, there were nearly 43 entries to Mexico; in 2010 the rate dropped to 30 entries and by 2016 it was reduced to a quarter of the figure reported at the beginning of the period; that is to say, the flow of Mexicans who have returned has been reduced in recent years. However, it is shown with estimates from the construction of panels with the INEGI methodology of international migrants, that the flow of people returning to the country continues involving each year, hundreds of thousands of people (Chart 1).

Chart 1. International immigrants born in Mexico, 2005-2016 (rates per 10 thousand inhabitants)

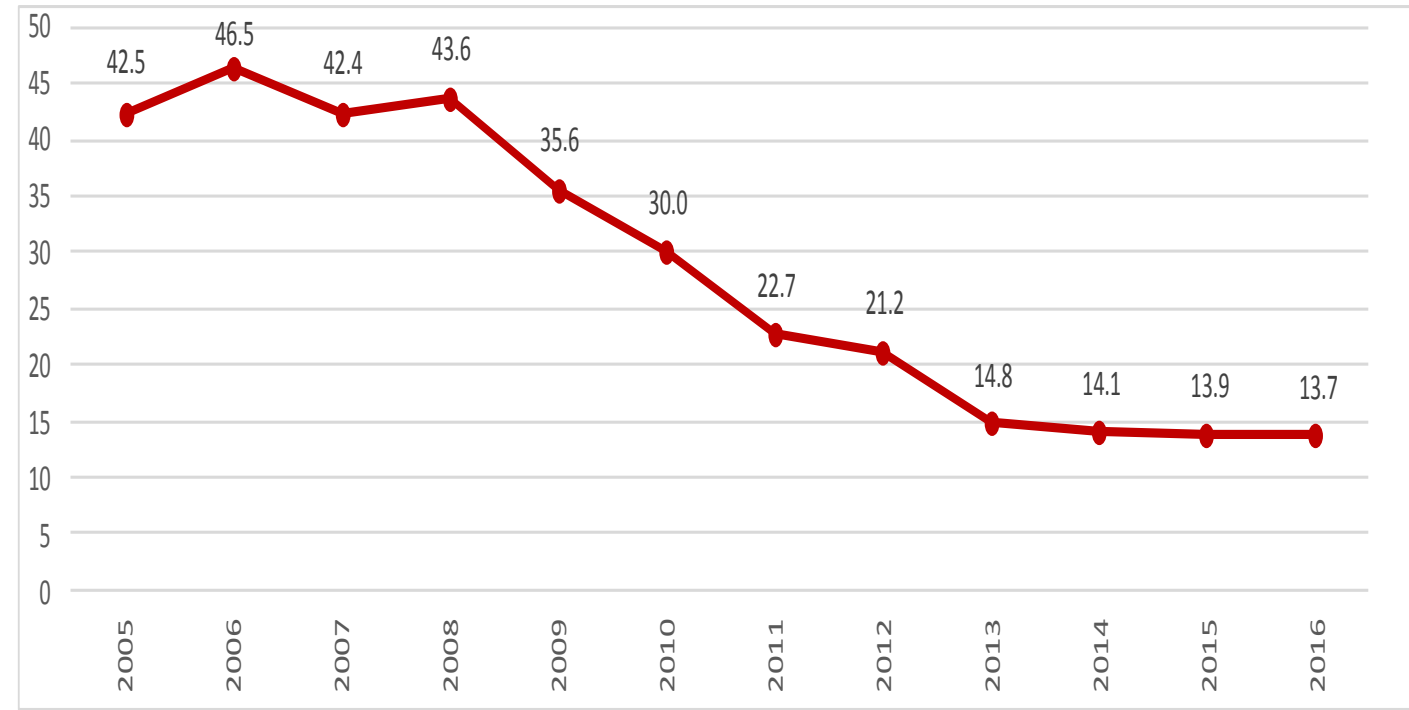

Source: Own compilation based on the construction of panels of the National Survey of Occupation and Employment (ENOE) INEGI 2005 - 2016.

Regarding the migration patterns of the population who arrived in Mexico in the last decade, data suggest that they have little changed. In general, according to the ENOE, it is young population in the productive age (average 33 and 39 years), that returns in greater proportion to urban locations.

This suggests that it is a population with high probability of requiring a job, although in proportion, return more men than women, which is consistent with the traditional pattern of Mexican migration to the United States (Table2). 
Table 2. Socio-demographic characteristics of flow for Mexican return migrants, 2010-2016

\begin{tabular}{|c|c|c|c|c|c|c|c|}
\hline \multirow{2}{*}{ Characteristics } & \multicolumn{7}{|c|}{ Years } \\
\hline & 2010 & 2011 & 2012 & 2013 & 2014 & 2015 & 2016 \\
\hline Sex & $100.0 \%$ & $100.0 \%$ & $100.0 \%$ & $100.0 \%$ & $100.0 \%$ & $100.0 \%$ & $100.0 \%$ \\
\hline Male & $78.4 \%$ & $79.8 \%$ & $72.9 \%$ & $81.3 \%$ & $79.5 \%$ & $74.4 \%$ & $75.1 \%$ \\
\hline Female & $21.6 \%$ & $20.3 \%$ & $27.1 \%$ & $18.8 \%$ & $20.5 \%$ & $25.6 \%$ & $24.9 \%$ \\
\hline Age & $100 \%$ & $100 \%$ & $100 \%$ & $100 \%$ & $100 \%$ & $100 \%$ & $100 \%$ \\
\hline $0-05$ years & $3.2 \%$ & $1.7 \%$ & $3.7 \%$ & $1.6 \%$ & $1.8 \%$ & $1.5 \%$ & $3.4 \%$ \\
\hline $6-11$ years & $1.1 \%$ & $1.9 \%$ & $1.7 \%$ & $0.7 \%$ & $0.7 \%$ & $2.1 \%$ & $2.0 \%$ \\
\hline 12-17 years & $3.9 \%$ & $2.7 \%$ & $5.5 \%$ & $1.3 \%$ & $1.3 \%$ & $1.6 \%$ & $2.6 \%$ \\
\hline 18-23 years & $14.4 \%$ & $21.4 \%$ & $13.7 \%$ & $13.7 \%$ & $14.4 \%$ & $12.4 \%$ & $15.9 \%$ \\
\hline 24-29 years & $21.8 \%$ & $20.8 \%$ & $16.5 \%$ & $20.4 \%$ & $17.0 \%$ & $18.8 \%$ & $17.0 \%$ \\
\hline 30-35 years & $18.8 \%$ & $16.2 \%$ & $15.9 \%$ & $15.7 \%$ & $20.9 \%$ & $13.9 \%$ & $9.5 \%$ \\
\hline 36-41 years & $14.4 \%$ & $11.5 \%$ & $13.6 \%$ & $14.3 \%$ & $12.7 \%$ & $13.2 \%$ & $19.2 \%$ \\
\hline $42-47$ years & $9.0 \%$ & $7.6 \%$ & $13.0 \%$ & $10.3 \%$ & $7.3 \%$ & $8.7 \%$ & $10.7 \%$ \\
\hline $48-53$ years & $5.5 \%$ & $6.0 \%$ & $5.1 \%$ & $11.2 \%$ & $4.8 \%$ & $7.4 \%$ & $7.9 \%$ \\
\hline $54-59$ years & $3.9 \%$ & $4.0 \%$ & $4.0 \%$ & $2.0 \%$ & $6.5 \%$ & $5.5 \%$ & $4.6 \%$ \\
\hline $60-65$ years & $2.0 \%$ & $2.8 \%$ & $3.0 \%$ & $3.2 \%$ & $5.5 \%$ & $5.5 \%$ & $2.8 \%$ \\
\hline 66 or older & $2.0 \%$ & $3.4 \%$ & $4.4 \%$ & $5.5 \%$ & $7.6 \%$ & $9.3 \%$ & $4.4 \%$ \\
\hline Average age & 33 & 33 & 34 & 36 & 38 & 39 & 36 \\
\hline Schooling & $100.0 \%$ & $100.0 \%$ & $100.0 \%$ & $100.0 \%$ & $100.0 \%$ & $100.0 \%$ & $100.0 \%$ \\
\hline No studies & $4.9 \%$ & $4.0 \%$ & $4.7 \%$ & $3.5 \%$ & $5.6 \%$ & $6.3 \%$ & $1.8 \%$ \\
\hline $\begin{array}{l}\text { Incomplete } \\
\text { elementary school }\end{array}$ & $14.3 \%$ & $14.4 \%$ & $15.5 \%$ & $15.8 \%$ & $11.4 \%$ & $14.5 \%$ & $14.6 \%$ \\
\hline $\begin{array}{l}\text { Complete elementary } \\
\text { school }\end{array}$ & $21.3 \%$ & $19.3 \%$ & $17.5 \%$ & $21.1 \%$ & $28.1 \%$ & $20.8 \%$ & $20.8 \%$ \\
\hline $\begin{array}{l}\text { Incomplete high } \\
\text { school }\end{array}$ & $3.9 \%$ & $5.2 \%$ & $5.4 \%$ & $4.7 \%$ & $2.4 \%$ & $2.4 \%$ & $4.1 \%$ \\
\hline Complete high school & $29.4 \%$ & $28.5 \%$ & $31.0 \%$ & $25.3 \%$ & $29.1 \%$ & $27.1 \%$ & $28.2 \%$ \\
\hline $\begin{array}{l}\text { Incomplete secondary } \\
\text { school } \\
\text { (baccalaureate) }\end{array}$ & $5.5 \%$ & $4.9 \%$ & $7.8 \%$ & $7.2 \%$ & $4.2 \%$ & $2.2 \%$ & $7.0 \%$ \\
\hline $\begin{array}{l}\text { Complete secondary } \\
\text { school } \\
\text { (baccalaureate) }\end{array}$ & $12.9 \%$ & $14.6 \%$ & $11.2 \%$ & $10.7 \%$ & $10.2 \%$ & $14.1 \%$ & $9.9 \%$ \\
\hline $\begin{array}{l}\text { College degree or } \\
\text { more }\end{array}$ & $7.8 \%$ & $9.1 \%$ & $7.0 \%$ & $11.8 \%$ & $9.0 \%$ & $12.6 \%$ & $13.6 \%$ \\
\hline Education & 8 & 8 & 8 & 9 & 8 & 8 & 9 \\
\hline Marital status* & $100.0 \%$ & $100.0 \%$ & $100.0 \%$ & $100.0 \%$ & $100.0 \%$ & $100.0 \%$ & $100.0 \%$ \\
\hline Single & $36.0 \%$ & $37.0 \%$ & $34.5 \%$ & $33.3 \%$ & $32.8 \%$ & $34.8 \%$ & $32.7 \%$ \\
\hline Married or civil union & $57.7 \%$ & $55.3 \%$ & $58.6 \%$ & $57.7 \%$ & $55.9 \%$ & $55.0 \%$ & $58.1 \%$ \\
\hline Sometime in union & $6.3 \%$ & $7.7 \%$ & $6.9 \%$ & $8.9 \%$ & $11.3 \%$ & $10.2 \%$ & $9.2 \%$ \\
\hline Place of residence $* *$ & $100.0 \%$ & $100.0 \%$ & $100.0 \%$ & $100.0 \%$ & $100.0 \%$ & $100.0 \%$ & $100.0 \%$ \\
\hline Urban & $61.9 \%$ & $61.7 \%$ & $59.8 \%$ & $56.7 \%$ & $63 \%$ & $62.3 \%$ & $61.9 \%$ \\
\hline Rural & $38.1 \%$ & $38.3 \%$ & $40.2 \%$ & $43.3 \%$ & $37 \%$ & $37.7 \%$ & $38.1 \%$ \\
\hline
\end{tabular}

Note: Percentages are estimated with respect to the total of valid answers, omitting the unspecified ones.

* Population aged 12 and older

** Rural places are the ones that have less than 2500 inhabitants.

Source: Own compilation based on the ENOE construction of panels 2010-2016, with INEGI methodology of international migrants. 
During the analysis period between 2010 and 2016, concerning the conjugal situation, more than $50 \%$ shows status as married or in a union, possibly due to the age structure that prevails among migrants. Regarding schooling, it is shown that the majority of migrants who return have low levels; on average, they reported between 8 and 9 years of schooling, associated possibly with the lower proportion of those who do not have schooling levels.

Derived from table 2, a significant proportion finished high school (the highest proportion appeared in 2012 with $31 \%$, and the lowest was the next year, with $25 \%$ in the analysis period). At the upper end of the distribution, after 2010,the proportion of returning migrants with university degrees increased a few percentage points, reaching about $14 \%$ towards the end of said period; this suggests that even for the most qualified returning migrants it could have been difficult to get a job in the current context of the United States.

A characteristic of the people who move from one place to another to work or to change their residence is their high percentage of participation in the economy. This applies to all return migrants that develop an economical activity due to the participation profile they have in the economically active population (PEA, for its acronym in Spanish), which is high in proportion: greater than 60\%, as displayed on the analysis period 2010-2016.

From the people aged 15 and over, almost 8 out of 10 have had some occupation during this period and about $20 \%$ are unemployed or looking for work, as it is shown in Table 3. With respect to economically inactive population (PEI, for its acronym in Spanish), the return migrants reported that nearly a third did not participate in some economic activity.

As it is shown in Table 2, it is seen that between 2010 and 2016 the majority of return migrants - around 52 and 61 percent -, are subordinated and wage workers; the proportion of self-employed workers increased from $18 \%$ to $32 \%$ between 2011-2015, meanwhile, by the end of that period, less than 7\% reported to be an employer. Year 2012 stands out with the greater proportion of employers, who were nearly $12 \%$, which suggests that the majority of them are returning with little resources to become self-employed and to create employments; in addition, their income is very low.

Table 3. Labour characteristics of flow of Mexican return migrants, aged 15 years and older, 2005 - 2016

\begin{tabular}{|l|c|c|c|c|c|c|c|}
\hline \multirow{2}{*}{ Characteristics } & \multicolumn{5}{|c|}{ Years } \\
\cline { 2 - 7 } & $\mathbf{2 0 1 0}$ & $\mathbf{2 0 1 1}$ & $\mathbf{2 0 1 2}$ & $\mathbf{2 0 1 3}$ & $\mathbf{2 0 1 4}$ & $\mathbf{2 0 1 5}$ & $\mathbf{2 0 1 6}$ \\
\hline Activity condition * & $\mathbf{1 0 0 . 0} \%$ & $\mathbf{1 0 0 . 0} \%$ & $\mathbf{1 0 0 . 0} \%$ & $\mathbf{1 0 0 . 0} \%$ & $\mathbf{1 0 0 . 0} \%$ & $\mathbf{1 0 0 . 0} \%$ & $\mathbf{1 0 0 . 0} \%$ \\
\hline $\begin{array}{l}\text { Economically Active Population } \\
\text { (EAP) }\end{array}$ & $64.8 \%$ & $68.8 \%$ & $64.3 \%$ & $67.8 \%$ & $63.7 \%$ & $61.8 \%$ & $66.3 \%$ \\
\hline $\begin{array}{l}\text { Economically Inactive Population } \\
\text { (EIP) }\end{array}$ & & & & & & & \\
\hline EAP & $35.2 \%$ & $31.2 \%$ & $35.7 \%$ & $32.2 \%$ & $36.3 \%$ & $38.2 \%$ & $33.7 \%$ \\
\hline Occupied & & & & & & \\
\hline No occupied & $\mathbf{1 0 0 . 0} \%$ & $\mathbf{1 0 0 . 0} \%$ & $\mathbf{1 0 0 . 0} \%$ & $\mathbf{1 0 0 . 0} \%$ & $\mathbf{1 0 0 . 0} \%$ & $\mathbf{1 0 0 . 0} \%$ & $\mathbf{1 0 0 . 0} \%$ \\
\hline EIP & $73.6 \%$ & $75.5 \%$ & $80.4 \%$ & $79.6 \%$ & $81.2 \%$ & $76.7 \%$ & $83.8 \%$ \\
\hline Available for work & $26.4 \%$ & $24.5 \%$ & $19.6 \%$ & $20.4 \%$ & $18.8 \%$ & $23.3 \%$ & $16.2 \%$ \\
\hline No available for work & $\mathbf{1 0 0 . 0} \%$ & $\mathbf{1 0 0 . 0} \%$ & $\mathbf{1 0 0 . 0} \%$ & $\mathbf{1 0 0 . 0} \%$ & $\mathbf{1 0 0 . 0} \%$ & $\mathbf{1 0 0 . 0} \%$ & $\mathbf{1 0 0 . 0} \%$ \\
\hline Position in the occupation & $32.7 \%$ & $29.5 \%$ & $22.9 \%$ & $32.1 \%$ & $29 \%$ & $23.5 \%$ & $24.0 \%$ \\
\hline $\begin{array}{l}\text { Subordinated and remunerated } \\
\text { workers }\end{array}$ & $67.3 \%$ & $70.5 \%$ & $77.1 \%$ & $67.9 \%$ & $71 \%$ & $76.5 \%$ & $76.0 \%$ \\
\hline Workers on their own & $\mathbf{1 0 0 . 0} \%$ & $\mathbf{1 0 0 . 0} \%$ & $\mathbf{1 0 0 . 0} \%$ & $\mathbf{1 0 0 . 0} \%$ & $\mathbf{1 0 0 . 0} \%$ & $\mathbf{1 0 0 . 0} \%$ & $\mathbf{1 0 0 . 0} \%$ \\
\hline Workers without payment & $57.1 \%$ & $61.5 \%$ & $55.9 \%$ & $59.1 \%$ & $58 \%$ & $52.3 \%$ & $53.1 \%$ \\
\hline Employers & $23.2 \%$ & $17.6 \%$ & $18.5 \%$ & $20.9 \%$ & $29 \%$ & $31.6 \%$ & $23.6 \%$ \\
\hline Economic activity & $15.5 \%$ & $16.5 \%$ & $15.1 \%$ & $12.9 \%$ & $9 \%$ & $13.3 \%$ & $16.0 \%$ \\
\hline Farming & $4.3 \%$ & $4.3 \%$ & $10.5 \%$ & $7.1 \%$ & $4 \%$ & $2.8 \%$ & $7.2 \%$ \\
\hline Services & $\mathbf{1 0 0 . 0 \%}$ & $\mathbf{1 0 0 . 0} \%$ & $\mathbf{1 0 0 . 0} \%$ & $\mathbf{1 0 0 . 0} \%$ & $\mathbf{1 0 0 . 0} \%$ & $\mathbf{1 0 0 . 0} \%$ & $\mathbf{1 0 0 . 0} \%$ \\
\hline Construction & $41.6 \%$ & $39.9 \%$ & $40.2 \%$ & $49.2 \%$ & $37.2 \%$ & $35.5 \%$ & $46.8 \%$ \\
\hline Manufacturing industry & $21.2 \%$ & $22.6 \%$ & $19.1 \%$ & $12.5 \%$ & $24.0 \%$ & $26.6 \%$ & $11.1 \%$ \\
\hline & $10.8 \%$ & $18.9 \%$ & $14.3 \%$ & $15.3 \%$ & $14.8 \%$ & $7.1 \%$ & $21.9 \%$ \\
\hline
\end{tabular}




\begin{tabular}{|l|c|c|c|c|c|c|c|}
\hline Commerce & $13.1 \%$ & $8.4 \%$ & $12.5 \%$ & $11.1 \%$ & $12.5 \%$ & $9.7 \%$ & $9.0 \%$ \\
\hline Others & $0.0 \%$ & $1.9 \%$ & $0.0 \%$ & $0.1 \%$ & $3.1 \%$ & $0.9 \%$ & $0.4 \%$ \\
\hline Income (**) & $\mathbf{1 0 0 . 0} \%$ & $\mathbf{1 0 0 . 0} \%$ & $\mathbf{1 0 0 . 0} \%$ & $\mathbf{1 0 0 . 0} \%$ & $\mathbf{1 0 0 . 0} \%$ & $\mathbf{1 0 0 . 0} \%$ & $\mathbf{1 0 0 . 0} \%$ \\
\hline Does not receive income & $23.7 \%$ & $23.6 \%$ & $26.8 \%$ & $19.2 \%$ & $19.3 \%$ & $22.6 \%$ & $26.5 \%$ \\
\hline Up to a minimum wage & $13.3 \%$ & $11.4 \%$ & $9.6 \%$ & $17.7 \%$ & $15.9 \%$ & $20.1 \%$ & $9.7 \%$ \\
\hline $\begin{array}{l}\text { More than 1 and up to 2 } \\
\text { minimum wages }\end{array}$ & $26.5 \%$ & $30.2 \%$ & $15.9 \%$ & $25.4 \%$ & $20.0 \%$ & $22.2 \%$ & $41.8 \%$ \\
\hline $\begin{array}{l}\text { More than 2 and up to 3 } \\
\text { minimum wages }\end{array}$ & $19.0 \%$ & $21.4 \%$ & $32.5 \%$ & $25.7 \%$ & $26.7 \%$ & $23.3 \%$ & $10.5 \%$ \\
\hline $\begin{array}{l}\text { More than 3 and up to 5 } \\
\text { minimum wages }\end{array}$ & $9.5 \%$ & $8.3 \%$ & $12.2 \%$ & $10.2 \%$ & $14.9 \%$ & $8.7 \%$ & $18.2 \%$ \\
\hline More than 5 minimum wages & $8.0 \%$ & $5.0 \%$ & $3.0 \%$ & $1.8 \%$ & $3.3 \%$ & $3.1 \%$ & $16.6 \%$ \\
\hline Labour formality ${ }^{(* * *)}$ & $\mathbf{1 0 0 . 0} \%$ & $\mathbf{1 0 0 . 0} \%$ & $\mathbf{1 0 0 . 0} \%$ & $\mathbf{1 0 0 . 0} \%$ & $\mathbf{1 0 0 . 0} \%$ & $\mathbf{1 0 0 . 0} \%$ & $\mathbf{1 0 0 . 0} \%$ \\
\hline No formal & $85.2 \%$ & $83.2 \%$ & $83.8 \%$ & $80.5 \%$ & $83.0 \%$ & $72.0 \%$ & $79.7 \%$ \\
\hline Formal & $14.8 \%$ & $16.8 \%$ & $16.2 \%$ & $19.5 \%$ & $17.0 \%$ & $28.0 \%$ & $20.3 \%$ \\
\hline
\end{tabular}

Note: Percentages are estimated with respect to the total of valid answers, omitting the unspecified ones

(1) People who during the reference period made or had an economic activity (employed population) or actively sought to have a job at some time during the month prior to the day of the interview (population not formally occupied) (Glossary INEGI, 2005).

(2) People who during the reference period did not perform or had an economic activity, nor did they seek to perform one at any time during the month prior to the day of the interview (INEGI, 2005).

(3) People who had a job in exchange for which he receives an economic remuneration in money.

(4) It is the occupied person who works alone or with the support of members of their own home or of others, but without the commitment to pay them for their services.

(5) Occupied person who helped or worked during the reference week in a business, company or family or nonfamily establishment, without any payment

(*) The labour characteristics describe population of 15 years and over.

(**) The average income is based on the minimum wage in Mexican pesos.

(***) Situation that distinguishes paid subordinate workers according to whether or not they have a signed formal contract that regulates their employment relationship with the economic unit for which they work.

Source: Own elaboration based on the ENOE construction of panels 2010 - 2016, with the INEGI international migrants methodology.

It was foreseen that for 2016, nearly $27 \%$ did not have any income at all; $62 \%$ earned between one and three minimum wages and only $18 \%$ earned more than three minimum wages. According to the analysis, on average for 2016, $80 \%$ of the population was part of the informal economy, an alarming fact since informality has a high correlation with poverty and social exclusion.

This suggests that the returnees of the last decade are not finding place in the formal labour market, and are incorporating in greater proportion to the informal economy labour market.

It is possible to identify certain characteristics, which would allow understanding the pattern of incorporation of returning migrants in informal employment in recent years, based on the information provided by the ENOE. With regard to sex, it is shown that men tend to enter informal jobs largely than women, but possibly, it is because women return in less quantity than men.

In terms of age, there is no a clear pattern to indicate whether this influences the decision of being or not informal. What the data suggest is that returning migrants are concentrated, in general in the productive age groups, that is, between 18 and 29 years old, followed by the group of those between 30 to 41 years old that in 2016 the youngest group reached nearly $40 \%$ in informality as opposed to a $28 \%$ of formal workers in that same rank of age. 
Another determinant that may be affecting the decision to work on informal activities is the education level. In this case, the data suggest that return migrants with lower education levels are prone to inserting informal works. In fact, it has to be pointed out that, in average, informal workers have between 2 and 4 years less of education levels than formal workers.

Regarding marital status of return migrants, it is not clear if having a partner makes them prone, or not, to informal works (the separated, widowers and married show a greater proportion to be in informal works rather than the unmarried, in free union and divorced ones). Something similar happens concerning kinship: this variable does not allow determining if to be the head of household, spouse or son affects in being informal work,or not.

Similarly, the variable for region does not allow concluding whether residing in some region in particular influences or not in being in informal work; what keeps happening is that they return in greater proportion to the traditional region, in disregard of being, or not in formal works. Concerning the size of location, data suggest that residing in a rural location, with populations of less than 2500 inhabitants, is related to a greater concentration of informal workers.

Table 4. Labour characteristics of Mexican return migrants flow, according to formal or informal employment, $2010-2016$

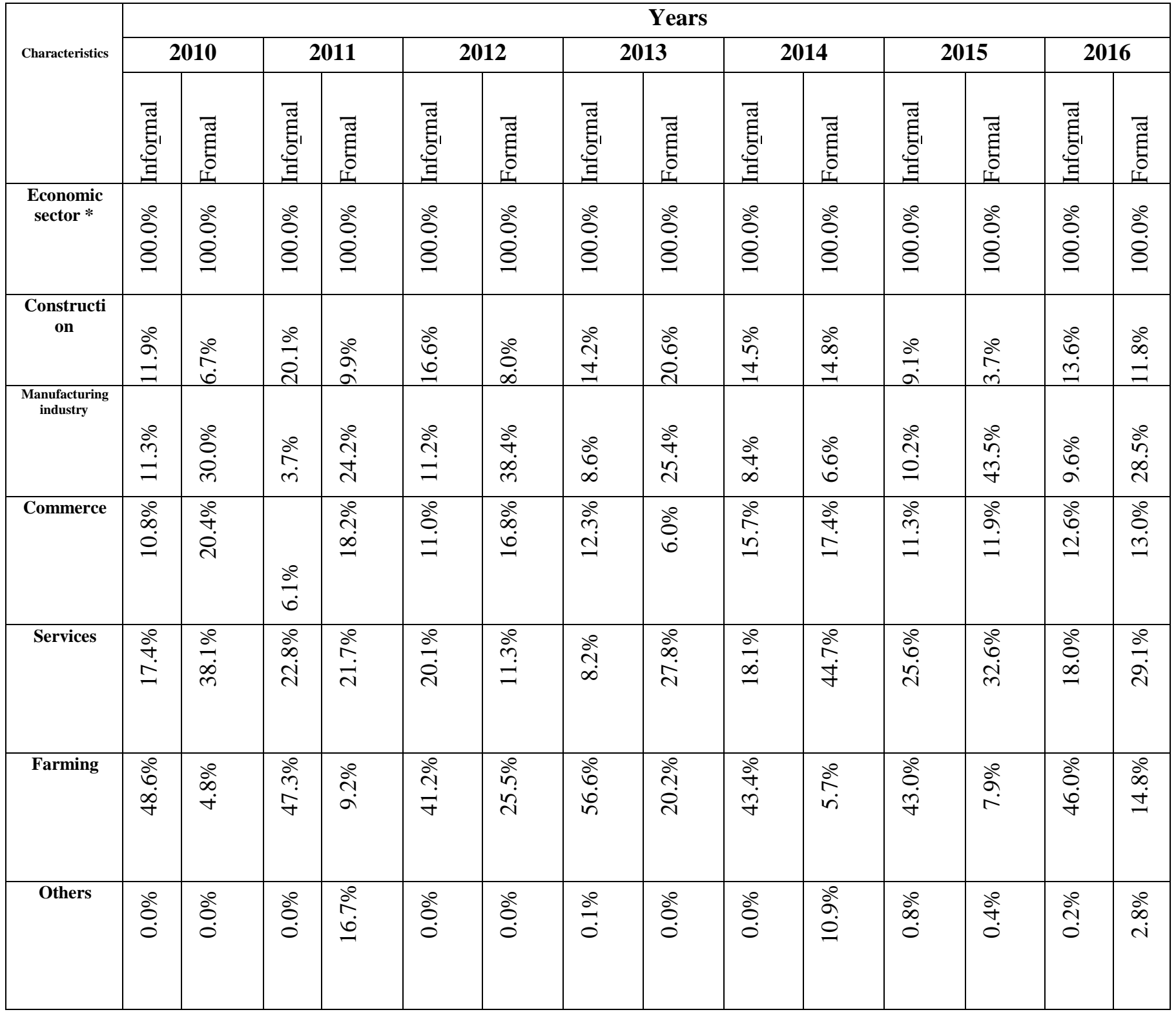




\begin{tabular}{|c|c|c|c|c|c|c|c|c|c|c|c|c|c|c|}
\hline $\begin{array}{l}\text { Post in the } \\
\text { occupation }\end{array}$ & $\stackrel{0}{8}$ & $\stackrel{\circ}{8}_{0}$ & $\stackrel{0}{8}$ & $\stackrel{\circ}{8}_{0}$ & $\stackrel{\circ}{8}_{0}$ & $\stackrel{0}{8}_{0}$ & $\stackrel{0}{8}_{0}$ & $\stackrel{\circ}{8}_{0}$ & $\stackrel{\circ}{8}_{0}$ & $\stackrel{\circ}{8}_{0}$ & $\stackrel{\circ}{8}_{0}$ & $\stackrel{\circ}{8}_{0}$ & $\stackrel{0}{8}_{0}$ & $\stackrel{0}{8}$ \\
\hline $\begin{array}{l}\text { Subordinated } \\
\text { and waged } \\
\text { workers }\end{array}$ & $\begin{array}{l}\infty \\
n \\
n \\
n\end{array}$ & $\frac{0}{20}$ & $\begin{array}{l}\stackrel{0}{a} \\
\text { ஜे }\end{array}$ & $\frac{\stackrel{\infty}{\infty}}{\infty}$ & $\begin{array}{l}\stackrel{8}{0} \\
\dot{+} \\
\dot{n}\end{array}$ & $\frac{2}{2}$ & $\begin{array}{l}\stackrel{\infty}{n} \\
\stackrel{n}{n}\end{array}$ & $\frac{\stackrel{8}{8}}{\stackrel{8}{+}}$ & $\begin{array}{l}\stackrel{0}{m} \\
i n\end{array}$ & $\begin{array}{l}\dot{0} \\
8 \\
\dot{0}\end{array}$ & $\begin{array}{l}\stackrel{\circ}{\mathfrak{j}} \\
\dot{f}\end{array}$ & $\begin{array}{l}\stackrel{\circ}{2} \\
\stackrel{n}{2}\end{array}$ & $\frac{\stackrel{0}{2}}{\frac{1}{n}}$ & $\begin{array}{l}\stackrel{0}{0} \\
\stackrel{0}{0}\end{array}$ \\
\hline $\begin{array}{c}\text { Self- } \\
\text { employed } \\
\text { workers }\end{array}$ & $\begin{array}{l}\stackrel{d}{b} \\
\stackrel{a}{a}\end{array}$ & $\stackrel{\substack{+r}}{r}$ & 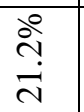 & $\frac{b}{i}$ & 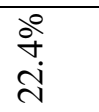 & 号 & $\begin{array}{l}b_{0} \\
\dot{0} \\
\infty \\
d\end{array}$ & ஜ̊ & 官 & $\begin{array}{l}\frac{2}{2} \\
\ddot{n}\end{array}$ & $\begin{array}{l}b_{0}^{0} \\
0 \\
\infty \\
m \\
m\end{array}$ & $\begin{array}{l}\stackrel{2}{n} \\
\stackrel{2}{=}\end{array}$ & $\frac{\dot{0}}{\dot{0}}$ & $\begin{array}{l}\stackrel{0}{2} \\
\ddot{n} \\
n\end{array}$ \\
\hline $\begin{array}{c}\text { Unpaid } \\
\text { workers }\end{array}$ & $\begin{array}{l}\infty \\
\infty \\
\infty \\
\infty\end{array}$ & $\begin{array}{l}8 \\
0 \\
0\end{array}$ & $\begin{array}{l}\stackrel{8}{+} \\
\stackrel{2}{a}\end{array}$ & 吕 & $\begin{array}{l}b 0 \\
b \\
\end{array}$ & $\stackrel{\circ}{0}$ & $\begin{array}{l}\frac{8}{r} \\
\dot{m}\end{array}$ & 吕 & $\begin{array}{l}\stackrel{0}{\rightleftarrows} \\
=\end{array}$ & $\frac{80}{6}$ & $\begin{array}{l}0^{\circ} \\
\infty \\
0 \\
0\end{array}$ & $\begin{array}{l}0 \\
0 \\
0\end{array}$ & $\begin{array}{l}ठ^{0} \\
\infty \\
\dot{J}\end{array}$ & $\begin{array}{l}\stackrel{0}{0} \\
\stackrel{+}{+}\end{array}$ \\
\hline Employers & $\frac{8}{0}$ & $\begin{array}{l}\stackrel{0}{2} \\
\stackrel{n}{1}\end{array}$ & $\begin{array}{l}b_{0}^{0} \\
\text { i }\end{array}$ & $\begin{array}{l}\infty \\
\infty \\
0 \\
0\end{array}$ & 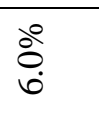 & $\begin{array}{l}\stackrel{d}{2} \\
\stackrel{d}{d}\end{array}$ & $\begin{array}{l}\stackrel{8}{n} \\
i \\
\forall\end{array}$ & $\begin{array}{l}80 \\
\dot{0} \\
9\end{array}$ & $\frac{d}{i}$ & 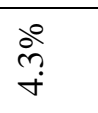 & $\underbrace{0}_{0}$ & $\begin{array}{l}b_{0}^{0} \\
\infty\end{array}$ & 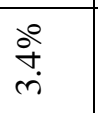 & $\begin{array}{l}\stackrel{Ð}{\mathfrak{I}} \\
\stackrel{ \pm}{ \pm}\end{array}$ \\
\hline Income & $\ddot{\dot{8}}_{0}$ & $\stackrel{\circ}{8}_{0}$ & $\begin{array}{l}0 \\
\stackrel{0}{8} \\
\end{array}$ & $\stackrel{\circ}{8}_{0}$ & $\stackrel{\circ}{8}_{0}$ & $\stackrel{\circ}{8}_{0}$ & $\stackrel{0}{8}_{0}$ & $\stackrel{\circ}{8}_{0}$ & $\stackrel{\circ}{8}_{0}$ & $\stackrel{\circ}{8}_{0}$ & $\stackrel{\dot{8}}{0}_{0}$ & $\stackrel{\dot{8}}{0}_{0}$ & $\stackrel{\ominus}{8}_{0}$ & $\stackrel{8}{8}$ \\
\hline $\begin{array}{l}\text { Do not } \\
\text { receive } \\
\text { income }\end{array}$ & 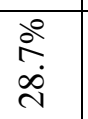 & $\begin{array}{l}\stackrel{0}{0} \\
0\end{array}$ & 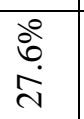 & $\stackrel{\circ}{0}$ & 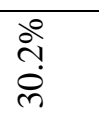 & 竞 & $\frac{\partial}{\ddot{n}}$ & 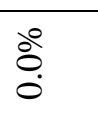 & $\begin{array}{l}\dot{0} \\
\dot{0} \\
\dot{\lambda}\end{array}$ & $\begin{array}{l}\stackrel{0}{0}^{\circ} \\
0\end{array}$ & $\begin{array}{l}\stackrel{0}{0} \\
\stackrel{0}{0} \\
\stackrel{d}{1}\end{array}$ & $\stackrel{0}{0}$ & 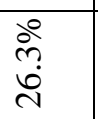 & $\stackrel{b}{b}$ \\
\hline $\begin{array}{c}\text { Up to one } \\
\text { minimal } \\
\text { wage }\end{array}$ & 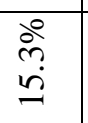 & $\stackrel{8}{0}$ & $\begin{array}{l}\stackrel{0}{2} \\
\stackrel{n}{1}\end{array}$ & $\begin{array}{l}\infty \\
i \\
\infty\end{array}$ & $\begin{array}{l}\stackrel{8}{8} \\
=\end{array}$ & 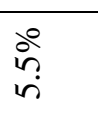 & $\begin{array}{l}\text { ปे } \\
\text { ปे }\end{array}$ & $\stackrel{\text { de }}{\text { i }}$ & $\begin{array}{l}\infty 0 \\
\infty \\
0 \\
0\end{array}$ & ஓ̆ & $\begin{array}{l}00 \\
\infty \\
i\end{array}$ & $\begin{array}{l}\text { ì } \\
\vdots \\
0\end{array}$ & $\begin{array}{l}\stackrel{0}{0} \\
\text { ஸे } \\
0\end{array}$ & 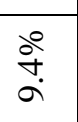 \\
\hline $\begin{array}{c}\text { More than } \\
1 \text { and up to } \\
2 \text { minimal } \\
\text { wages }\end{array}$ & $\vec{\sim}$ & $\stackrel{i}{2}$ & $\dot{m}$ & $\stackrel{10}{0}$ & $\stackrel{2}{\circ}$ & $n_{n}^{n}$ & $\stackrel{\dot{\imath}}{\stackrel{2}{r}}$ & $\stackrel{\infty}{\stackrel{0}{0}}$ & $\dot{\vec{\lambda}}_{i ̊}$ & $\stackrel{9}{2}$ & $\stackrel{\stackrel{+}{\sim}}{\stackrel{\leftrightarrow}{2}}$ & $\stackrel{2}{2}$ & तें & $\stackrel{i}{ }$ \\
\hline $\begin{array}{c}\text { More than } \\
2 \text { and up to } \\
3 \text { minimal } \\
\text { wages }\end{array}$ & $\stackrel{\infty}{\sigma}$ & $\stackrel{9}{0}$ & $\stackrel{\infty}{\infty}$ & $\stackrel{\text { mे }}{\stackrel{\sim}{2}}$ & $\stackrel{\vec{\lambda}}{a}$ & in & $\stackrel{\infty}{\stackrel{0}{m}}$ & in & $\stackrel{d}{i}$ & $\stackrel{\ddot{n}}{\infty}$ & $\stackrel{\ddot{n}}{\stackrel{0}{2}}$ & $\stackrel{\infty}{\stackrel{\infty}{+}}$ & $\begin{array}{l}\dot{\sim} \\
\dot{0}\end{array}$ & $\dot{n}$ \\
\hline $\begin{array}{c}\text { More than } \\
3 \text { and up to } \\
5 \text { minimal } \\
\text { wages }\end{array}$ & $\dot{0}$ & के & $r^{\circ}$ & $=$ & 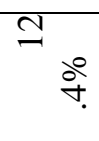 & $=$ & $\stackrel{\infty}{\circ}$ & $\stackrel{\infty}{\stackrel{0}{?}}$ & $\stackrel{m}{0}$ & ปิ & $a^{\circ}$ & $\stackrel{7}{\simeq}$ & \begin{tabular}{ll|}
$\circ$ & \\
& 0 \\
& $\infty$ \\
& 0
\end{tabular} & $\because$ \\
\hline $\begin{array}{c}\text { More than } \\
5 \text { minimal } \\
\text { wages }\end{array}$ & $\begin{array}{l}\stackrel{0}{0} \\
\dot{d} \\
\text { i }\end{array}$ & $\begin{array}{l}\frac{0}{n} \\
\text { ஸे }\end{array}$ & $\stackrel{\circ}{=}$ & $\stackrel{\stackrel{\circ}{n}}{m}$ & $\begin{array}{l}0 \\
b \\
0\end{array}$ & $\stackrel{\text { ก̊ }}{=}$ & $\stackrel{b}{b}$ & $\frac{\circ}{i}$ & $\frac{b^{\circ}}{\dot{0}}$ & $\frac{b}{2}$ & $\stackrel{\circ}{\circ}$ & $\begin{array}{l}\ddot{0} \\
0 \\
0\end{array}$ & $\stackrel{80}{=}$ & ڤ̊ \\
\hline
\end{tabular}

Note: percentages are estimated in respect of the total amount of valid responses, omitting the no specified ones.

(*)The labour characteristics are for population aged 15 and older.

Source: Unit of Migratory Policy, estimates from the ENOE construction of panels 2010 - 2014, with the INEGI international migrants methodology. 
There are a greater proportion of informal workers in the agriculture and construction sectors in comparison to other economic sectors such as commerce, services and manufacturing industry. Likewise, the position in their occupation affects the possibility of being formal or informal, a higher proportion of self-employed or unpaid workers are informal.

The ENOE data also show that returning migrants with low income, of up to two minimum wages, are more prone to be informal. In fact, it can be observed that there is a significant gap from the 3 minimum wages, where a greater proportion is found in the formality (Table 4).

To sum up, the socio-demographic profile of the returnees, combined to the current situation of labour markets in Mexico as in the United States as well, poses new challenges for those who have decided to return to the country and to public policies, since it is a population with migratory experience and that requires to be incorporated to productive life and to be reintegrated socially, although current circumstances prevent some return migrants to come back into real favourable economic conditions, even if they, for example, sent remittances or if they contributed with their savings that made up during their stay in the United States, in order to reintegrate as self-employed workers, and/or bringing into play their accumulated human capital (Rivera, 2011).

It is important to mention that the analysis shown until now is limited, since it allows only to observe "the gross" effects of the returning migratory condition about the insertion in the labour market in an informal occupation, without establishing to what extent these effects are the outcome per se referring to the migratory situation, or they are reflected in other socio-demographic characteristics associated with the condition of return migrants, that puts them at disadvantage in the labour market.

On the other hand, it arises the need to examine the effect of the international migratory experience in conjunction with other kind of structural variables, in order to determine the possibility that a return migrant can insert in an informal occupation, such as occupation, age, studies, sex, type of location, income, the size of economic unit, among others. This can be achieved with the application of regression models, which will occupy the next section of this work.

\section{Results of the determinants of the informality among Mexican return migrants}

The estimates carried out in this section consider the variables that the literature suggests as important in the determination of the types of employment that workers have access to; however, we are aware of the limitations in the availability of information inherent to the source.

The variables that will be used in the analysis for the logistic regression models are: sex(male and female), age (from 15 to 33, and older than 34 years), marital status (in union or not), kinship (son/daughter and other), schooling (up to 9 years, and more than 9 years of schooling), region of residence (Traditional region and Other region), Type of location (Locations smaller than 2500 inhabitants, and Locations with more than 2500 inhabitants), Income (Income up to two minimum wages, and More than three minimum wages), Position in the occupation (Employer and Non Employer), Size of the economic unit (Micro business and Not micro business).

The statistical information corresponding to the variables of the model comes from the ENOE, which offers information on a set of socio-demographic variables related to the work market, at home scale. In order to obtain data from the returning migrants in the first instance, the bases of the first quarter of 2010 were merged up to the first quarter of 2017, to determine the variables to be taken into consideration in the model that, according to theory, affects a returning migrant's probability of insertion in the informal work.

The ENOE defines formal employment as the waged workforce that has access to a social security scheme, while the informal is related to activities that are carried out with households' resources, even though those are not well identified and duly established companies, independent from their households (INEGI, 2014; Varela et al., 2013).

Commonly, it is pointed out that people who are more likely to insert into informal jobs are those who have little work experience, low education, females, and are not head of household, among others. However, it is important, prior to the analysis of the determinants of the informality among Mexican return migrants, to make a primary exercise of exploration about the association or independence among the explanatory variables and the dependent variable; these bi-variant associations are examined by means of the analysis of the contingency tables; this allows to obtain, in a general way, an idea of the independent effects of the different variables on the probability of obtaining an informal job (Table 6). 
Table 6. Main results of the contingency tables

\begin{tabular}{|c|c|c|c|c|c|c|}
\hline \multirow[t]{2}{*}{ Variables } & \multirow{2}{*}{$\begin{array}{l}\text { Pearson's } \\
\text { Chi-square } \\
\text { value }\end{array}$} & \multirow[t]{2}{*}{ gl. } & \multirow{2}{*}{$\begin{array}{l}\text { Asymptotic } \\
\text { significance } \\
\text { (bilateral) }\end{array}$} & \multirow[t]{2}{*}{ Odds } & \multicolumn{2}{|c|}{$\begin{array}{l}\text { Intervals of confidence of } \\
\text { odds }\end{array}$} \\
\hline & & & & & Lower & Upper \\
\hline Sex & 2.59 & 1 & 0.108 & 1.44 & 0.92 & 2.26 \\
\hline Age & 1.88 & 1 & 0.170 & 0.79 & 0.56 & 1.11 \\
\hline $\begin{array}{l}\text { Marital } \\
\text { status }\end{array}$ & 0.34 & 1 & 0.559 & 1.11 & 0.79 & 1.55 \\
\hline Kinship & 1.09 & 1 & 0.297 & 0.83 & 0.59 & 1.17 \\
\hline $\begin{array}{l}\text { Years of } \\
\text { schooling }\end{array}$ & 25.58 & 1 & 0.000 & 2.41 & 1.71 & 3.40 \\
\hline $\begin{array}{l}\text { Residence } \\
\text { region }\end{array}$ & 2.57 & 1 & 0.109 & 1.32 & 0.94 & 1.85 \\
\hline $\begin{array}{l}\text { Kinds of } \\
\text { location }\end{array}$ & 13.13 & 1 & 0.000 & 2.76 & 1.56 & 4.87 \\
\hline Income & 39.27 & 1 & 0.000 & 3.73 & 2.43 & 5.73 \\
\hline $\begin{array}{l}\text { Position in } \\
\text { the } \\
\text { occupation }\end{array}$ & 7.72 & 1 & 0.005 & 2.53 & 1.29 & 4.95 \\
\hline $\begin{array}{l}\text { Size of the } \\
\text { economic } \\
\text { unit }\end{array}$ & 164.91 & 1 & 0.000 & 10.66 & 7.16 & 15.87 \\
\hline
\end{tabular}

Note: Estimates from the construction of panels, with the methodology of international migrants from INEGI.

Source: Own elaboration, based on the National Survey of Occupation and Employment (ENOE), INEGI 2005-2016.

The results of the analysis show in this exercise, and given the limitations of the source of information, that there is no evidence enough that might suggest any association between being an informal worker, and variables such as sex, age, marital status, kinship, and region of residence, which is opposite to what literature suggested, reason why these variables were left behind for this part of the analysis because of showing statistical independence.

Abovementioned does not mean that the process of occupational insertion in the informal sector, at least for this exercise, is not related to these variables, on the contrary these continue having a roll but their effects operate on a indirect way by means of other variables such as schooling, kind of location, income, position in an occupation, among others. The effects of variables: years of schooling, kind of location, income, position in the occupation and the size of the economic unit, regarding the probability of being in the informal work, are examined using a logistic model where the dependent variable is a dichotomous variable which value is equal to one if the returning migrant belongs to informal work, and zero if he is not. This way it is intended to calculate the probability of a return migrant to be in the informal work through a set of socio-demographic and labour variables that characterize informality.

Also an analysis is performed to detect possible strong variables, and if detected, to proceed to adjust or control them in order to avoid that the main relation among the explanatory variables and the dependent one is not spurious. Other variables of interest would be those that could be interacting in terms of increase or decrease the effect of the main relation. The technique used was the stratified method and the multi-variant analysis, procedures that allow data adjust or control. Since there are multiple factors affecting returning migrants' probabilities of being immerse in an informal work, there is a multidimensional explanation that allows knowing the effects of the migratory experience controlled by other characteristics, by watching the logistic regression of returning migrants born in Mexico. The method that was chosen for this was "input", using the criterion of the ratio of maximum verisimilitude.

\subsection{Estimated model of return migrants}

In the design of the estimated model, first three measures are reported to evaluate the their overall validity: first is the value of -2LL, and the other two are Coefficients of Determination $\left(R^{2}\right)$ in which: a perfect model would have a very small value of -2LL (ideally, zero), and $\mathbf{R}^{2}$ near to one (ideally, one) - Nagelkerke's R-Square is a corrected version of 
the Cox and Snell's R-square. The Cox and Snell's R-square has a maximum value less than 1, even for a "perfect" model -. The Nagelkerke R-squared corrects the statistical scale to cover the full range from 0 to 1(Table 7).

Table7.Summary of the estimated model

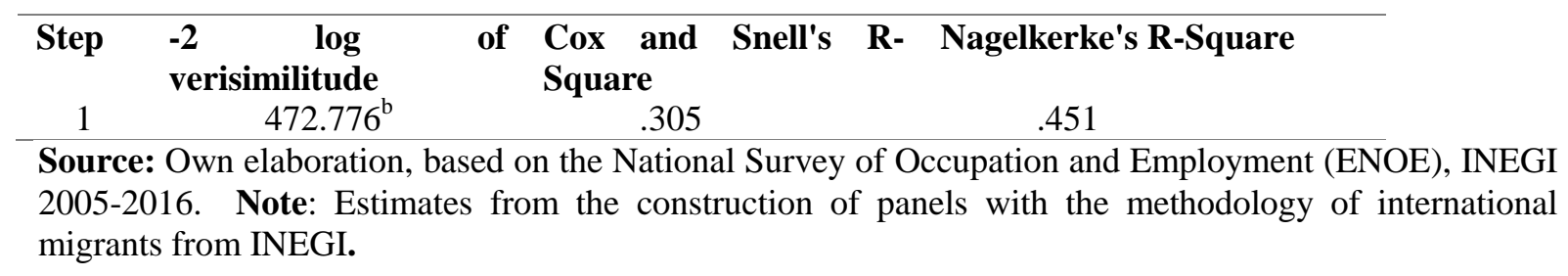

For this particular case, the data suggest that the overall validity of return migrants estimated model is good, Nagelkerke's square R does not indicate that the model explains a 45 percent of the variability of the studied problem, which is enough, given the complexity of the phenomenon, and the own limitations of the source.

For this estimative, the Test of Hosmer and Lemeshow is also used. This test of goodness of adjustment is based on the idea that if the adjustment is good, a high value of the predicted probability $(p)$ will be associated with result 1 of the dependent binomial variable, whereas a value under $p$ (close to zero) would correspond (in most of cases) with the $\mathrm{Y}=0$ result.

It is about calculating, for each observation of the data set, the probabilities of the dependent variable that the model predicts; sort them, gather and calculate from them, the expected frequencies and then compare them with the ones observed through a square Chi test (Table8).

This goodness of adjustment test has some details: the statistic of Hosmer and Lemeshow is not calculated when, for some groups, $\mathrm{E}_{\mathrm{i}}$ (expected values) or $\mathrm{E}_{\mathrm{i}}^{*}\left(\mathrm{n}_{\mathrm{i}}-\mathrm{E}_{\mathrm{i}}\right.$ ) are null or very small (less than 5). What is expected in this test is that there is no significance (contrary to what is usual).

Table 8. Hosmer \& Lemeshowtest

\begin{tabular}{rrrr}
\hline \multicolumn{1}{c}{ Step } & Chi squared & \multicolumn{1}{c}{ D.F. } & Sig. \\
1 & 7.213 & 8 & .514 \\
\hline
\end{tabular}

- Hosmer \& Lemeshow Test

\begin{tabular}{ccccccc}
\hline & & $\begin{array}{l}\text { Type of sector } \\
\text { employment }\end{array}$ & $=$ Formal & $\begin{array}{l}\text { Type of sector } \\
\text { employment }\end{array}$ & Informal & Total \\
Observed & Expected & Observed & Expected & \\
Step 1 & 1 & 48 & 50.633 & 21 & 18.367 & 69 \\
& 2 & 39 & 37.120 & 23 & 24.880 & 62 \\
& 3 & 29 & 24.383 & 23 & 27.617 & 52 \\
& 4 & 13 & 17.056 & 43 & 38.944 & 56 \\
& 5 & 7 & 6.671 & 43 & 43.329 & 50 \\
& 6 & 7 & 9.120 & 105 & 102.880 & 112 \\
& 7 & 3 & 3.091 & 54 & 53.909 & 57 \\
& 8 & 2 & 1.035 & 22 & 22.965 & 24 \\
& 9 & 5 & 3.129 & 99 & 100.871 & 104 \\
& 10 & 0 & .763 & 47 & 46.237 & 47 \\
\hline
\end{tabular}

Note: Estimates from the construction of panels with the methodology of international migrants from INEGI.

Source: Own elaboration, based on the National Survey of Occupation and Employment (ENOE), INEGI 2005-2016.

As a way to evaluate the regression equation and the obtained model, a table $2 \times 2$ is created to classify all the individuals from the sample (Table9), according to concordance of observed values with the predicted or estimated ones of the model, in a similar way as diagnosis tests are evaluated. 
Table 9. Classification table

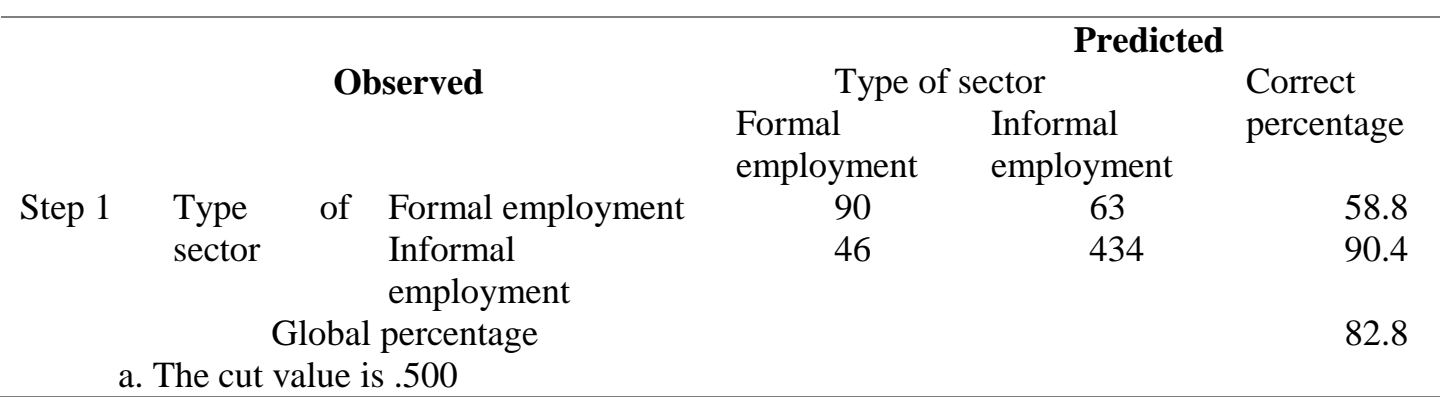

Note: Estimates from the construction of panels with the methodology of international migrants from INEGI.

Source: Own elaboration, based on the National Survey of Occupation and Employment (ENOE), INEGI 2005-2016.

In the classification table it can be verified that the model has a specificity of 58,8 percent and a sensitivity of 90,4 percent. With the constant and five explicative variables, it classifies in a 82,8 percent all returning migrants in an informal job that $(\mathrm{Y}=1)$ when the cut point of the calculated probability $\mathrm{Y}$ is settled down (by default) in 50 percent $(0,5)$ (Table 8$)$. In chart 2 of classification, it can be observed a representation of what is happening:

Chart 2. Forecast probabilities of the studied groups

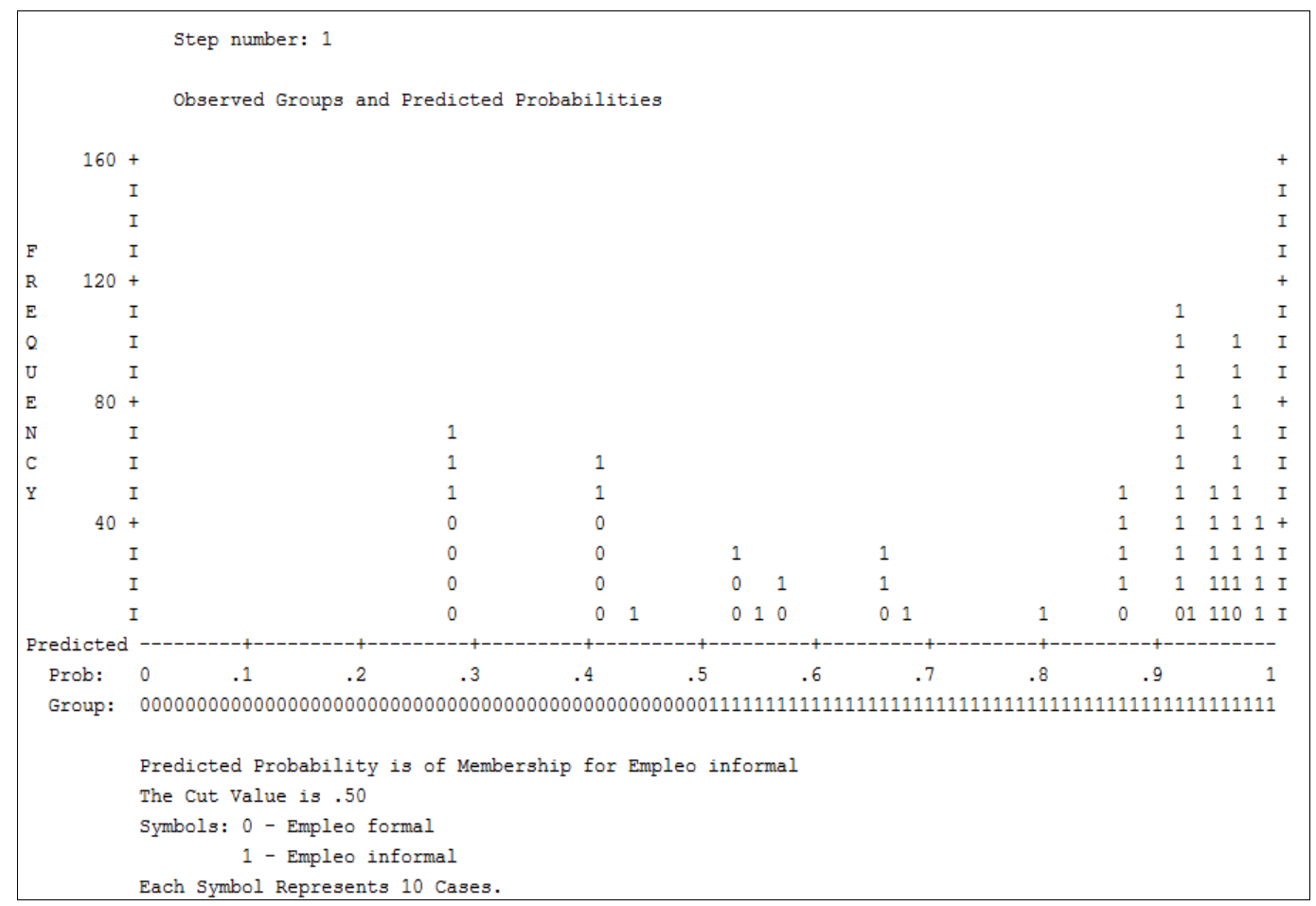

Note: Estimates from the construction of panels with the methodology of international migrants from INEGI.

Source: Own elaboration, based on the National Survey of Occupation and Employment (ENOE), INEGI 2005-2016.

To sum up, in chart 2 it is possible to observe how the model expresses probabilities for Y lesser and greater to 0,5 ; this suggests a good predictive power of the model for both values of the dependent variable, which in this case are formal and informal work.

Finally, the regression model is presented, adjusted by controlling the selected characteristics. It also includes the regression coefficients with their corresponding standard errors, as well as the value of the Wald statistic for evaluating the null hypothesis $\left(\beta_{i}\right)$, the associated statistical significance, and the value of the OR (exp (B)), with their confidence intervals (Table 10). 
Table10. Determinants of informality among Mexican returning migrants. Odd ratios of the logistic regression model

\begin{tabular}{|c|c|c|c|c|c|c|c|c|}
\hline \multirow{9}{*}{$\begin{array}{l}\text { Step } \\
1\end{array}$} & \multirow{5}{*}{$\begin{array}{l}\text { T_Location } \\
(1) \\
\text { Schooling } \\
\text { years (1) } \\
\text { Income (1) }\end{array}$} & \multirow{3}{*}{$\begin{array}{l}\infty \\
.677\end{array}$} & $\stackrel{\leftrightarrow}{\dot{H}}$ & $\begin{array}{l}\frac{\pi}{\pi} \\
\frac{\pi}{3}\end{array}$ & $\frac{.00}{n}$ & \multirow{2}{*}{$\begin{array}{l}\widehat{0} \\
0 \\
0 \\
\text { a } \\
1.968\end{array}$} & \multirow{2}{*}{$\begin{array}{l}95 \% \text { C.I. } \\
\text { (B) } \\
\text { Lower } \\
.995\end{array}$} & \multirow{3}{*}{$\begin{array}{l}\text { for EXP } \\
\text { Upper } \\
3.892\end{array}$} \\
\hline & & & & 3.785 & & & & \\
\hline & & & 348 & & 052 & & & \\
\hline & & .552 & & 5.475 & & 1.737 & 1.094 & 2.758 \\
\hline & & 1.050 & & 16.741 & 019 & 2.858 & 1.728 & 4.726 \\
\hline & & & 257 & & 000 & & & \\
\hline & $\begin{array}{l}\text { Possition_ocu } \\
\text { p (1) }\end{array}$ & 1.675 & 494 & 11.491 & 001 & 5.340 & 2.027 & 14.069 \\
\hline & TUE (1) & 2.823 & & 120.372 & & 16.831 & 10.164 & 27.871 \\
\hline & Constant & -2.628 & & 25.005 & & .072 & & \\
\hline
\end{tabular}

Note: Estimates from the construction of panels with the methodology of international migrants from INEGI.

Source: Own elaboration, based on the National Survey of Occupation and Employment (ENOE), INEGI 2005-2016.

\subsection{Estimated results}

Location. By controlling the size of location, years of schooling, income, position in the occupation and the size of the Economic Unit, the odds indicate that a returning migrant residing in localities with less than 2500 inhabitants, is more likely to be immerse in informal employment by two times; that is to say, working in rural or less urban localities, increases the odds of being involved in informal employment.

This creates serious disadvantages for the rural returnees residents, where the educational and employment opportunities are very scarce; thus, the problem of insertion of such people to the social and occupational structure gets worse.

Schooling. Regarding schooling years, the odds suggest that those who have less than nine years of schooling, the informal employment probability is 1,7 times more likely, which suggests that schooling is conditioning the choice of the type of job. This means that the provision of better educational credentials is an advantage in the labour market, which in particular affects the access to formal occupations and to greater status in which there is greater competition.

Income. Concerning the income, the odds suggest that returning migrants who perceive less than two minimum wages are 2,8 times more likely to be immersed in informal employment. Income affects the choice of the type of employment, so that a low income is an indication of greater informality; on the other hand, it is expected that a greater availability of income is associated with the possibility of a greater effort to avoid informality, which is a residual sector or escape to unemployment, whose activities provide income only for survival. The odds also suggests that no employers are 5,3 times more likely to be immersed in the informal employment than the employers. But when it is controlled by the Size of the Economic Unit, the odds show that being involved in micro business is 16,8 times more probable to be immerse in informal employment.

From the set of socio-economic variables analyzed, the Size of the Economic Unit, is the variable with increasing weight that is conditioning the choice of the type of employment (see table 9). In synthesis, our results suggest that informality is a residual sector of escape from unemployment, where the work force that could not be incorporated into the formal sector tends to create small business, with a small number of employees in marginal activities of low productivity.

\section{Conclusions and recommendations}

The purpose of this study was to determine the factors that affect a returning migrant's probability of being immersed on work informality. That is to say, the interest is to know which were the characteristics of returning workers with a greater incidence on informal jobs. Our results suggested that current returning migrants have found few opportunities in the formal labour market, what lead them to join the informal sector of the economy, but not by the fact of being returning migrants, but because they tend to have few economic attributes, little human and physical capital. 
Likewise, we found that the informal sector is also linked to the decisions that employees and employers take, motivated perhaps by certain advantages that this sector may be offering. But it was when controlling by the Size of the Economic Unit,that results indicated that if they are part of a microbusiness, the informal employment probability is more likely to occur, that shows that informal activities can be a segment test to entrepreneurship, not to mention that the current situation of labour markets is also influencing the choice of the type of employment, preventing to some returning migrants to go back to more favourable economic conditions, preventing them to benefit from its effort and migratory experience to reach a better work performance and incorporate to formal work.

Derived from abovementioned, it is evident that to be able to increase the formal Mexican job market, increasing levels of education becomes indispensable; also, generating the conditions of employment stability must be created through more stable recruiting schemes. Similarly, it stands out that informal employment when is associated with small production units or micro businesses, forces to boost these establishments, with the intentions that the labour segment comprising it transit towards greater labour formality in medium-sized and large establishments, where predominates a greater long-term business vision. The economic, political and social unfavourable scenery of the last years, that is showing with the advent to power of government representatives with anti-immigrant positions, as it is the case of the current President of the United States, Donald Trump and his insistence on plans for mass deportations of Mexicans, in addition to the construction of a wall on the border, not only led to the worst crisis ever in the Mexico-United States relationship, but also has complicated the scenario for the compatriots in that country, particularly for those who are in an irregular situation, because it is forcing them to constantly rethink about their return; the question is: would Mexico be prepared for the return of migrants?, which also requires social policies best suited to their profiles. First, it would be necessary to generate mechanisms so the civil organizations and migrants, put pressure on the local governments (state and municipalities) to design and operate programs for reintegration that are appropriate to their particular conditions, regardless of the current difficult economic situation.

Secondly, taking into account the need for a development of State policy, and a new institutional architecture that articulates migration, development and human rights, to avoid that at a long-term, the social welfare levels of social structure continues its deterioration.

Finally, this study suggests the need to make greater efforts to glimpse with greater precision, the determinants of labour informality among Mexican returning migrants, as well as the gaps existing in the information sources.

The contribution of the exploratory study and the findings generated by the results showed advances in precision and delivery of new information by themselves, in the sense that there is still very little knowledge about the determinants of labour informality, which certainly constitutes a scientific knowledge about the analysis of the processes of social and professional integration of returning migrants.

\section{References}

Alarcón, R., R. Cruz, A., Díaz, G., González, A., Izquierdo, G., \& Zenteno, R., (2008), "La crisis financiera en Estados Unidos y su impacto en la migración mexicana", El Colegio de la Frontera Norte.

Alarcón, R., (2008), El retorno de los migrantes, La Jornada, 28 de octubre. http://www.jornada.unam.mx/2008/10/28/index.php?section=opinion\&article=016a1pol

BBVA-Bancomer (Fundation), (2012), Los migrantes que regresan: ¿quiénes y en qué condiciones laborales lo hacen?, Situación Migración México. Análisis Económico. https://www.fundacionbbvabancomer.org/imagenes/docs/SitMig_2012Jul.pdf

Canales, A., (2012), La migración mexicana frente a la crisis económica actual. Crónica de un retorno moderado, Revista Interdisciplinar da Mobilidade Humana, Brasília, 20(39), 117-134.

Castells, M \& Portes, A., (1989),World underneath: The origins, dynamics and effects of the informal economy, in Portes, A., Castells, M. \& Benton, L. (eds.), The informal economy studies in advanced and less developed countries, Baltimore, Johns Hopkins Press, pp. 11-37.

Consejo Nacional de Población (CONAPO), (2012), Índices de Intensidad Migratoria México-Estados Unidos 2010, México, CONAPO.

De Soto, H., (1987), El Otro Sendero. La Revolución Informal, Instituto Libertad y Democracia, Lima. , (2000), El Misterio del Capital, El Comercio, Lima.

Fields, G., (1975), Rural-urban migration, urban unemployment and underemployment, and job-search activity, in Journal of Development Economics, Elsevier, 2(2), 165-187.

García, G., (2011), Determinantes macro y efectos locales de la informalidad laboral en Colombia, in Revista Sociedad y Economía, 21, 69-98. 
Garduño, S., (2012), Crece retorno de paisanos, Reforma, sección Nacional, 9 de marzo, http://reforma.vlex.com.mx/vid/crece-retorno-paisanos-356491522

Harris, J. R., \& Todaro, M., (1970), Migration, Unemployment and Development: a Two-Sector Analysis, American Economic Review, 60(1), 126-142.

Hart, K., (1970), Small-Scale Entrepreneurs in Ghana and Development Planning, The Journal of Development Studies, 6(4), 104-120.

(1973), Informal Income Opportunities and Urban Unemployment in Ghana, Journal of Modern African Studies, 11(1), 61-89.

Hirschman, A., (1970), Exit, Voice, and Loyalty: Responses to Decline in Firms, Organizations, and States, Harvard University Press.

Instituto Nacional de Estadística, Geografía e Informática (INEGI), (2011), Mujeres y hombres en México, Instituto Nacional de Estadística, Geografía e Informática, Instituto Nacional de las Mujeres, http://www.inegi.org.mx/prod_serv/contenidos/espanol/bvinegi/productos/integracion/sociodemografico/mujer esyhombres/2011/MyH2011.pdf.

Instituto Nacional de Estadística, Geografía e Informática (INEGI), (2014), La informalidad laboral. Encuesta Nacional de Ocupación y Empleo. Marco conceptual y metodológico, Instituto Nacional de Estadística, Geografía e Informática, http://www.inegi.org.mx/est/contenidos/Proyectos/encuestas/hogares/regulares/enoe/doc/Informalidad_marcomet.pdf

Martínez, J., (2008), Empleo informal y segmentación del mercado de trabajo urbano en México, (Tesis), España, Universidad Autónoma de Barcelona, Departamento de Economía Aplicada.

Mestries, F., (2013), Los migrantes de retorno ante un futuro incierto, Sociológica, 28(78), 171-212.

Mincer, J., (1976), Unemployment Effects of Minimum Wages, The Journal of Political Economy, 84(4), S87-S105.

Mohar, G., (2014), Programa Especial de Migración Habemus, in Excelsior ,http://www.excelsior.com.mx/opinion/gustavo-mohar/2014/05/11/958606

Mora, Minor \& Oliveira, O., (2011), Jóvenes Mexicanos en medio de la crisis económica: los problemas de la integración laboral, Revista Sociedad y Estado, 26(2), 373-421.

OIT, (1972), Incomes, employment and equality in Kenya. Geneva: International Labour Office.

Passel, J., D. Cohn, \& Gonzalez, A., (2012), Net Migration from Mexico Falls to Zero and Perhaps Less, Washington, DC: Pew Hispanic Center.

Passel, J. \&Cohn, D., (2011), Unauthorized Immigrant Population: National and State Trends, 2010, Washington, DC, Pew Hispanic Center.

Passel, J.\& Cohn, D. (2009).Mexican Immigrants: How Many Come? How Many Leave? Washington, DC, Pew Hispanic Center.

Powers, D.\& Xie, Yu,(2000), Statistical Methods for Categorical Data Analysis. New York, Academic Press.

PREALC, (1981), Dinámica del Subempleo en América Latina. Santiago de Chile. , (1985), Más allá de la Crisis, Oficina Internacional del Trabajo, Santiago de Chile.

Rivera, L., (2011), ¿Quiénes son los retornados? Apuntes sobre el migrante retornado en el México contemporáneo, in Feldman, B. Et. Al., La construcción social del sujeto migrante en América Latina. Prácticas, representaciones y categorías, Quito, Facultad Latinoamericana de Ciencias Sociales y Consejo Latinoamericano de Ciencias Sociales, 309-338.

Samaniego, N., (2009), La crisis, el empleo y los salarios en México, Revista de Economía, UNAM, 6(16), 57-67.

Secretaría de Gobernación (SEGOB), (2014), Programa Especial de Migración 2014-2018, México, Diario Oficial de la Federación, 30 de abril, http://www.dof.gob.mx/nota_detalle.php?codigo=5343074\&fecha=30/04/2014

Tokman, V., (1987), El sector informal: quince años después, El trimestre económico, 215, Fondo de Cultura Económica, México.

Trejos, J., (2001), El trabajo decente y el sector informal en los países del istmo centroamericano, Informe preliminar, OIT, Costa Rica.

Tuirán, R. \&Ávila, J., (2013), ¿De la fuga a la circulación de talentos?, Revista Este País, 266, 32-35.

Valderrey S.,(2010). SPSS 17 Extracción del conocimiento a partir del análisis de datos, México, Alfaomega.

Varela, R., Castillo \& R., Ocegueda, J., (2013), El empleo formal e informal en México: un análisis discriminante, Papeles de Población, 19(78), 111-140.

Vargas, E. \& Cruz, R., (2014), Búsqueda de empleo entre jóvenes de acuerdo a su participación y protección laboral en México, Papeles de población, 20(81), 213-245. 